Lukasz Gemziak

Toruń

\title{
Образ Запада в восприятии Виктора Ерофеева
}

Ключевые слова: Виктор Ерофеев, западническая традиция в современной России, современная интеллектуальная жизнь в России, Россия - Запад, менталитет и капитализм Запада

Виктор Ерофеев является современным русским писателем, творчество которого воспринимается неоднозначно. В своих литературных произведениях и публицистических статьях автор Русской красавиць затрагивает один из существенных вопросов русской культуры - вопрос восприятия Запада и отношения к нему. У русского писателя, благодаря детству, проведенному во Франции ${ }^{1}$, многочисленным путешествиям (См.: Ерофеев [2008е]) и знакомствам с представителями Запада, сложилось довольно многогранное представление о странах Западной Европы и США르, ставшее важной частью его общественно-политических взглядов. Отсутствие углубленных исследований в этой области стало причиной настоящей попытки проанализировать важнейшие произведения Ерофеева в этом контексте ${ }^{3}$.

1 Ерофеев в беллетризованной форме описывает этот период своей жизни в романе Хороший Сталин. См.: Ерофеев [2010с], (в частности, 127-204).

2 Следует сказать, что восприятие Запада через призму различных стереотипов и нереальных представлений привело некоторых российских мыслителей и писателей (например, Михаила Бакунина, Александра Герцена) к жестокому разочарованию. В результате часть из них стала противниками Запада [Кантор 2001, 14].

3 Материалом для исследований являются, прежде всего, публицистические статьи. В меньшей степени используются эссе и литературные произведения. 
Предметом исследований в настоящей статье является система взглядов Виктора Ерофеева в контексте «классического» западнического мировоззрения ${ }^{4}$. Рассматриваются связи между убеждениями автора Хорошего Сталина и ценностями западнической традиции 5 .

Мировоззрение Ерофеева раскрывается через отношение русского писателя к Западу, его культуре, особенностям западного менталитета и капитализма, а также рассматривается в контексте взглядов писателя на современные политико-общественные отношения между Россией и Западом.

\section{1. «Скучная Европа»}

Образ Запада, создаваемый русским писателем, является результатом сравнения с Россией. Ерофеев, наблюдая за особенностями Западной Европы и США, почти никогда не забывает об опыте жизни в СССР и России. Такой взгляд, заключающий в себе представление о разнообразии мира и возможность сравнивать его с собственной культурой, оказывается довольно интересным и указывает на характерные, несвойственные России, черты Запада. При этом автор Энииклопедии русской души не забывает и о том, что страны Западной Европы во многом отличаются от США.

Ерофеев, описывая Европу, замечает, что ее состоятельный, благополучный образ жизни несет определенные опасности:

Европа живет по инерции. Волки, которые могут съесть Европу, это ее отощавшие и переродившиеся ценности. Это ценности, которые все больше лишаются своего первичного содержания и существуют в основном в формальном измерении. [...] Если проанализировать жизнь европейского человека, то в ней нет главного - в ней нет смысла жизни. [...] Общество потребления сделало европейца заложником моды. Работа превращается в гонку за второсортным престижем. [...] Европеец постоянно занят, даже отдых он превратил в занятие, которое не оставляет его один на один с самим собой. Это и есть бестелесные волки Европы: человек потерял представление о самопознании. Самопознание из экзистенциальной категории

4 Основные для классического западничества ценности - это личность, индивидуальность, свобода, одухотворенность (понимаемая рационально - как сознательность, пытливость), «разумность» человека, терпимость, возможность свободного обмена идеями и культурными ценностями, равенство и социальная справедливость. См.: Щукин [2001, 139-144].

5 Термин «мировоззрение» употребляется в значении целостного представления о мире, системы ценностей (этических, эстетических и других). Cм.: Walicki $[1964,8]$. 
перешло в категорию практического знания о красоте, здоровье и времяпрепровождении. Жизнь стала скучной, но скука не замечается изнутри этой жизни, потому что жизнь заполнена до предела борьбой за достойную с точки зрения общей нормы жизнь [Ерофеев 2006b, 10].

Главной угрозой для Европы является она сама, - замечает Ерофеев. Культура потребления стала доминирующим признаком Европы, отвергнуты духовные составляющие, а вместо них не найдены безопасные альтернативы. Европа создает явления и ценности, которые перерождаются в реальную опасность ${ }^{6}$. Писатель обращает внимание на то, что некоторые европейские ценности уже переменялись, и их облик видоизменился:

Идеология Европы свелась к набору общеупотребительных понятий. [...] Либерализм превратился в толерантность. Была утрачена иерархичность культуры как форма неуважения к электорату. Культура стала горизонтальной. Власть между тем сохранила свою пирамидальность, но об этом неприлично говорить. Европейцы почувствовали дискомфорт пустоты и вернулись к архаике национализма. Это еще один волк, против которого пока что есть слабая защита - объединение континента. Однако протест против Европейской конституции - это неверно найденная точка боли [Ерофеев 2006b, 10-11].

Старый свет стал местом, где больше всего ценится собственное спокойствие и мирная жизнь. Однако европейцы не знают, какую цену придется им заплатить за такое поведение. Никто не обращает внимания на то, что происходит рядом, что является сутью изменений. Ведь возрождение националистических тенденций не является положительным способом решения каких-либо проблем, подчеркивает Ерофеев. Европа, погруженная в нерефлексивную жизнь, пытается поверхностно справиться со сложными вопросами: «Борьба с курением - только

6 С точки зрения вопросов, рассматриваемых в настоящей статье, очень интересным является тот факт, что даже идея негативного образа Запада была сформулирована самими европейцами. В эпоху романтизма некоторые (преимущественно консервативные) немецкие философы и писатели, словно в ответ на французские победы времен Наполеона и связанное с ними навязывание культурных ценностей Просвещения, пытались защитить свою культуру. Большую роль сыграл здесь Иоганн Гердер и его концепция «духа народа». Немецкие взгляды об исключительности собственной культуры и ее отличии от «цивилизации западноевропейской» (Великая Британия и Франция) в XX веке стали основой националистических движений в Рейхе. Конечно, задолго до этого некоторые идеи, связанные с негативным образом Запада, появлялись также в других странах Европы или даже за ее пределами, но начали развиваться в другом направлении. (О европейских истоках антизападных убеждений и развитии этих концепций см.: Buruma, Margalit [2005, в частности, с. 54-63]. 
первый шаг. Если футбол плодит агрессию болельщиков, почему бы не кастрировать футбол? [...] Европа утрачивает свою человеческую живописность» [там же, 11]. Странам Западной Европы хотелось бы избавиться от всех возможных опасностей и они пытаются это сделать. Однако меры, к которым они прибегают, имеют исключительно мирный характер. Европа «бросилась в кусты от бандитов с большой дороги» [там же], однако ей не удалось спрятаться. Русский писатель утверждает, что невозможно «уничтожить любые жизненные риски» [там же], потому что в человеке заложены черты, которые к ним стремятся. Нельзя избавиться от агрессии, свойственной сущности человека [там же]. Убежденность в доброй человеческой природе, восходящая корнями к эпохе Просвещения и проявляющаяся в вере в рациональное поведение человека и в прогресс, обманчива ${ }^{7}$. Автор Русской красавицbl, подчеркивая существование негативной стороны человеческой натуры, одновременно замечает, что Европа все еще верит, несмотря на опыт истории, в полностью предсказуемого человека. Это убеждение лежит в основе желания мирно и безопасно решать все проблемы. В результате оказывается, что Европа не осознала опыта времен тоталитаризма ${ }^{8}$.

Хорошая, благополучная жизнь общества является явным преимуществом Европы, замечает Ерофеев. Однако нельзя забывать и о собственных несовершенствах, особенно в политическом плане. К ним относятся своего рода неопределенность и отсутствие серьезных решений. Мещанская Европа не желает никаких перемен. Ее равнодушие удивляет и, одновременно, вызывает презрение: «Не имея ни Бога, ни атеизма, не имея ярко выраженных правых и левых форм политической жизни, она все больше становится предметом насмешки со стороны тех самых иммигрантов, которых она когда-то из чувства вины и политической щедрости пригласила к себе» [Ерофеев 2006b, 11]. Ерофеев подчеркивает, что Европа является слишком предсказуемой. При столкновении с неожиданными явлениями эта европейская особенность может серьезно помешать ей успешно справиться с возникшими проблемами.

7 Ирина Скоропанова подчеркивает, что «Виктора Ерофеева человек интересует больше всего как источник зла, переполняющего мир [...]». [Скоропанова 2002, 194]. Вопрос садизма, зла и других негативных склонностей, заложенных в психике человека, рассматривается Ерофеевым в литературных эссе. См., например: Ерофеев [2006c, 222-273; 1985, 140-158].

8 Зло, существующее в натуре человека, стало темой многих книг о тоталитаризме. См., например, [Arendt 1977]. 
Следует добавить, что, говоря о Европе, русский писатель уделяет внимание также странам Центральной Европы и Прибалтики, присоединившимся к политическим и военным структурам Запада. Однако он не считает их полностью западными странами. Их собственная история, в том числе и коммунистическое прошлое, является аргументом в пользу такого мнения 9 .

Своеобразная «скучность поведения» отличает страны Западной Европы от США, прежде всего, в политическом плане. Можно предполагать, что причиной такой ситуации является нежелание Европы играть роль гегемона в мире. Политики Старого света смирились со своей второстепенной, но все еще влиятельной, позицией. Кажется, что такая ситуация вполне их устраивает. С другой стороны, попытки мирного урегулирования каких-либо общественных и политических конфликтов могут вытекать также из исторического опыта. Британский историк Тони Джадт замечает, что американцы мыслят иначе, чем европейцы, которые уже не в состоянии представить себе войну как реальное событие со всеми его негативными последствиями. В результате Штаты остаются единственной развитой страной, где милитаризм все еще одобряется [Judt 2008, 6-7].

Образ жизни стран Западной Европы и США в общественном плане сходен. В качестве примеров можно привести отношение к духовному, религиозному вопросу.

\section{2. Духовные вопросы}

Одной из особенностей Запада, вызывающей изумление россиян, является отсутствие пристального интереса к духовной жизни. Русский писатель указывает на истоки этого явления и называет его типичной чертой США и стран Западной Европы:

Ницше сказал: «Бог умер» - и Европа это восприняла как последнее слово о Боге (хотя умер не Бог, умерло старое представление о Боге). Поэтому, когда на Западе кто-нибудь произносит слово «метафизика», в глазах собеседника паника. Он думает: или перед ним дурак, которого охмурили родители-католики, или человек, помешанный на Востоке. Восток

9 Среди стран Средней Европы автор Русского апокалипсиса особенно интересуется Польшей. См., например: Ерофеев [2002, 21; 2008h, 142-146; 2004a, 460-463, 2010b; 2008f, 225-229; 2003а]. Многие статьи и интервью Ерофеева (преимущественно касающиеся России) публикуются на польском языке. 
там считается дешевым поветрием. Все футболисты, регбисты, киноактеры, режиссеры - буддисты. Нам это кажется духовными поисками, а для нормального жителя Берлина или Парижа впасть в буддизм - все равно что у нас стать приверженцем Жириновского [Ерофеев 2001, 32].

Европа исключила метафизические, духовные вопросы из своего сознания. Сфера религии, веры или духовных поисков оказалась вне общественного интереса и в настоящее время может существовать только в контексте личной жизни. Русским писателем подчеркивается факт, что такое положение вещей привело к отсутствию какого-либо разнообразия в области европейских идей, связанных с духовными проблемами. Именно этим оправдываются поиски нематериальных ценностей, направленные, в основном, на Восток. Ерофеев утверждает, что своего рода исключением, современной европейской попыткой справиться с жизненно важными вопросами, является философия экзистенциализма [там же], но этого недостаточно. Тем не менее автор Русского aпокалипсиса не считает жизни на Западе безнравственной. Там существуют моральные, связанные с христианством принципы, но они выполняют своеобразную роль: «На Западе все построено на законах рынка. Рынок стабилизирует мораль, рынку нужно, чтобы все помирились и пахали. И люди подчиняются рынку - так спокойнее. Но момент отчаяния все равно возникает - отсюда искания, метания...» [там же]. Писатель подчеркивает, что нравственность, иногда связанная с религией и метафизической философией, превратилась на Западе в обычные правила поведения, которые способствуют развитию капиталистической экономики. Духовный контекст не является уже основополагающим или вообще исчезает. В результате жители Запада не находят ничего, что могло бы выполнять истинную функцию религии, связанную с духовными переживаниями.

Ерофеев повторяет свой основной упрек в сторону обществ Западной Европы и США. Ради спокойствия и мирной жизни они слишком часто избегают ответа на важные вопросы. Рынок предлагает им интересоваться внешними аспектами жизни и «кастрировать» все вопросы, которые могут их от этого отвлечь. Именно поэтому при разговоре о духовности на Западе «в глазах собеседника паника».

Замечания Ерофеева о западных проблемах духовности характеризует довольно высокая степень обобщения. Автор Энииклопедии русской души уделяет мало внимания разнообразию Запада в этом аспекте. Ведь, к примеру, сравнивая религиозность в США, можно сказать, что жители крупных городов и люди, живущие в провинции, придер- 
живаются двух различных моделей поведения. Однако Ерофееву удается уловить суть основных перемен в вопросе религиозности - преобладающим все больше становится атеистический или равнодушный к религии образ жизни ${ }^{10}$.

\section{Political correctness, опасное мнение большинства и антидемократические тенденции}

Очередным вопросом, свидетельствующим о желании западных обществ жить мирно и без каких-либо конфликтов, является политическая корректность. В многонациональном обществе уважение к человеку, составляющее основу рассматриваемого явления, - это хороший способ наладить правильные отношения: «Но американцы воспитаны так, что врать нельзя и смеяться над другими нехорошо. [...] Чтобы в таком смешанном обществе, как Америка, относиться к другому так, как хочешь, чтобы он относился к тебе, надо начинать с нуля. [...] Самоограничение порождает эпидемию самоограничений» [Ерофеев 2008d, 47-48].

Ерофеевым одобряется американское самоограничение, которое превращается во взвешенность и уважительное отношение к другим людям. Однако позитивное, как идея, стремление никого не обидеть может вести к странному поведению. Русский писатель, участвуя в репетициях к опере Жизнь с идиотом (по мотивам своего одноименного рассказа) в Амстердаме, имел возможность столкнуться с желанием оказаться политически корректным:

Директор Амстердамской Оперы Пьер Аудин был деловым и знающим человеком. [...]

- Есть проблема, - сказал он при закрытых дверях. - У нас в опере роль Идиота поет негр. [...]

- Ну и что?

- Попечительский совет нашей Оперы был на репетиции. Понимаешь, у нас в Голландии получается политически некорректным, если «черный» поет Идиота.

Я не поверил его словам. Но он явно не шутил. Нужно было что-то предпринимать.

- Давай перекрасим его в белый цвет, - предложил я.

10 Анджей Шахай замечает, что процесс секуляризации идет во всех странах культуры Запада, за исключением США и Польши [Szahaj 2012, 97]. 
- Идея! - обрадовался Пьер. [...]

- Ну, как? - спросил я Пьера после репетиции. [...]

- Ты что не видишь? - взорвался Пьер. - Белым он выглядит полным издевательством над негром! Сквозь белую краску еще сильнее проступает его негритянская морда! Нам этого не простят! [Ерофеев 2008a, 65-66].

Западная политкорректность удивляет Ерофеева своими последствиями. Попытки избежать всевозможных, даже надуманных конфликтов, значительно осложняют жизнь общества. При этом такие усилия носят преимущественно поверхностный характер. В результате оказывается, что политкорректность обладает и значительными отрицательными чертами.

На Западе дела, касающиеся индивидуальных выборов человека, нередко решает мнение большинства. Именно поэтому русский писатель воспринимает Запад как место, в котором меньшинство, по принципу имеющее возможность свободно принимать решения о своей судьбе, подчиняется большинству. Большинство, в свою очередь, пытается как можно более усложнить «опасные» действия остальной части общества, например, предостерегая об угрозах определенных выборов или вводя соответствующие законы. Таким образом, преобладающий взгляд становится политкорректным. Ерофееву такое поведение кажется очень странным:

Мои позиции отличались идейной путаностью. Я курю, но в принципе я против курения. Я понимаю все значение его вреда, но мне не совсем понятно, зачем продавать сигареты в магазинах [...], если на каждой пачке страшными черными буквами написано, что табак убивает или что «курение сделает вас импотентом». Я - за демократию, но, зная судьбы литературы и науки, вроде астрономии, в Европе прошлых веков, я осторожно отношусь к мнению большинства, стараясь как можно меньше ему подчиняться. Очевидно, что Европа двинулась за Соединенными Штатами Америки в борьбе за здоровую жизнь, смысл которой и решает демократическое большинство, избравшее Буша или, например, запретившее аборты в Польше [Ерофеев 2004c, 20].

«Идейная запутанность» русского писателя вытекает из уверенности в том, что различные ценности могут сосуществовать рядом друг с другом. Политическая корректность и мнение большинства вытесняют из общественной жизни другие суждения и модели поведения, не приемля менее популярных образов жизни. Ерофеев опасается последствий такой ситуации и в этом случае его поведение очень похоже на «непоследовательность», о которой писал Лешек Колаковский: 
В том смысле, в котором мы сейчас говорим, непоследовательность - это просто отказ от принимаемого раз и навсегда предопределяющего выбора между какими-либо взаимно исключающимися ценностями.

[...] это попытка создания определенного мировоззрения. Последнее признает, что крайности непримиримы, но не желает от них отказаться, поскольку признает ценности и той и другой крайности [Колаковский $1974,302 ; 305]$.

Политкорректность является результатом очередной «переродившейся ценности». Идея, которая по существу должна бороться против нетерпимости, ксенофобии и других отрицательных явлений, оказывается лишь средством для вынесения сложных проблем за пределы общественного диспута.

«Последовательность» большинства можно заметить также в других ситуациях. Перемены, происходящие в странах Европы и США, напоминают прагматическую игру, которая до сих пор ассоциировалась у Ерофеева с российской политикой: «После конца холодной войны [Запад - Ł.G.] [...] все больше пропивается духом строгости и подчинения авторитету. Западные страны с традиционной демократией зарабатывают оруэлловские очки, когда высокомерно говорят от имени истины, спекулируют на политической корректности» [Ерофеев 2008g, 255].

Говоря об «оруэллах» или «оруэлловских очках», Ерофеев имеет в виду антидемократические тенденции в определенных странах. По его мнению, двойственность принципов и забота о собственном интересе делают из Запада, особенно из США, политический субъект, который перестает четко отличаться от России: «Уничтожение „оруэллов” в чужих странах, зараженных диктатурой, вроде бывшего Ирака, нередко ведется Западом по-оруэлловски. Буш с Путиным могли бы при встречах обмениваться личными „оруэллами” в порядке самозачетов» [там же, 256].

Поведение Запада, зарабатывающего «оруэллы», сказывается и на самой России. Ведь определенная часть россиян воспринимает Запад как некую цель, к которой должна стремиться их родина. Писатель замечает, что отсутствие противопоставления России и Запада может оказаться отрицательным фактором: «Запад, перестающий быть культурной альтернативой для русских - это подрыв русской цивилизации. За таким Западом не хочется следовать. В какую сторону идти?» [там же, 255]. 


\section{4. Достоинства Запада и западное восприятие России}

Говоря о недостатках Запада, Ерофеев не забывает подчеркнуть и его отдельные достоинства, суть которых проступает при сравнении с Россией. Автор Русского апокалипсиса утверждает, что одной из положительных черт стран Европы и США является социальная поддержка со стороны государства, служащие которого умеют выстроить систему помощи для сограждан:

Можно смеяться над наивностью американцев, но Америка реально создала социальные программы помощи старикам и безработным, малоимущим и калекам. Эти программы осуществляются людьми, которые любят свою работу, умеют помогать людям в беде. Не только Америка, но и весь цивилизованный мир дает возможность молодым семьям получить кредит на покупку достойного жилья. Это называется нормальной жизнью [Ерофеев 2008b, 144-145].

Также американский образ жизни, связанный с идеей «жизненного успеха», одобряется Ерофеевым. Русский писатель замечает, что для граждан США - это точный культурный ориентир, которого все еще не хватает в России. Влияние этой мысли очень сильно: «Вот американское кино бьет в одну и ту же точку, бьет и все время подпитывает идею индивидуального успеха в жизни. Это абсолютно суперпротестантская ценность, имеющая неисчерпаемый ресурс жизненности в Америке. И они там тысячи раз смотрят фильмы про одно и тоже» [Ерофеев 2003b, 47].

Ерофеев не забывает, что образ России на Западе не менее важен для взаимоотношений, чем восприятие Запада в глазах России. Именно поэтому он обращает внимание также на вопрос западных представлений о своей родине.

Автор Хорошего Сталина приходит к выводу, что страны Европы и США относятся к России с большим недоверием. Одним из примеров этому стала проблема въезда в Евросоюз через восточную границу. Писатель утверждает, что:

В какой-то степени это напоминает границу между США и Мексикой - границу перепада цивилизаций и качества жизни. [...] В список провинившихся стран, которых надо охватить пограничной заботой, кроме России, попали межеумки: Белоруссия и Украина. Однако, скорее всего, эти осколки Империи находятся во временном карантине, как холерные корабли. Пусть сначала выблюют из политического желудка взбесившегося Лукашенко, перестанут тайно торговать оружием, помоют голову шампунем. Радужных надежд на Россию не возлагается. Европейские дипломаты 
в Москве на мой вопрос, когда будет отменен визовый режим с Европой, отвечают ласково и уклончиво, как врачи - родственникам умирающего [Ерофеев 2003d].

Приводя пример границ между ЕС и РФ, Ерофеев пытается понять, где именно лежит причина того, что Запад не желает иметь более тесных взаимоотношений с Россией. Он замечает, что не существует объективных причин, которые могли бы этому препятствовать. Евросоюзу не следует опасаться русской мафии или бедной России ведь с преступностью лучше бороться вместе, а Румыния не богаче России [там же]. Скорее всего, виной возникшей ситуации является стереотипное восприятие России как другой цивилизации, к тому же неравноправной Западу. Получается, что «речь все-таки идет о диких восточных ордах, которых рисовал в своем политическом воображении Гитлер и хотел уничтожить после евреев» [там же]. Такое восприятие восточного соседа ${ }^{11}$ EC не идет на пользу, как и в случае с «оруэллами», самому Западу. Напротив, отталкивание России несет в себе определенную опасность:

Отталкивая Россию, Европа подрывает в ней демократические силы, близкие Европе, и поощряет тех, кто не любит ни Европу, ни свободу прессы, мечтает о российском «фундаментализме». Подарок коммунистам и Жириновскому. Вроде бы не трудно понять, что на самом деле опасна изолированная Россия. [...]

Боязнь России - хроническая болезнь Европы. Это болезнь высокомерия, лицемерия, невежества. Лекарства от нее не найдено [там же].

Ерофееву, который сам довольно сильно критикует Россию, не хотелось бы, чтобы Запад относился к его родине как к враждебной стране. Вследствие такой обстановки к власти в России могут прийти антизападные силы. В результате любые попытки связать Россию с Западом окажутся невозможными. Русский писатель, опасаясь такой

\footnotetext{
11 Следует сказать, что представление о россиянах как «восточных ордах», связанных с Азией, существует и в русской культуре. Оно отразилось, например, в поэзии Валерия Брюсова, Владимира Соловьева. Своеобразным художественным символом

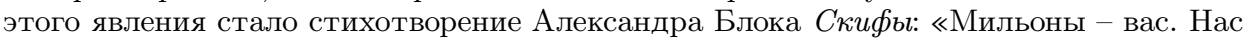
- тьмы, и тьмы, и тьмы./ Попробуйте, сразитесь с нами!/ Да, скифы - мы! Да, азиаты - мы,/ С раскосыми и жадными очами! [...]». См.: Блок [1960, 360]. Наличие азиатского влияния на Россию подчеркивали также сторонники евразийства - философско-политического течения, которое зародилось в 20-е годы ХХ в. в эмиграции. См., например: Bäcker [2000].
} 
политической ситуации, надеется на Запад, который должен притягивать всех своих восточных соседей и пытаться поддерживать с ними хорошие отношения. Ерофеев рассчитывает и на возможность беспрепятственного посещения россиянами стран ЕС и США [Ерофеев 2004 e, 23]. Не исключено, что их мировоззрение изменится так же, как в свое время поменялось мировоззрение будущих декабристов. Именно для этого нужен безвизовый режим [Ерофеев 2010а].

Запад болен страхом перед Россией. От этой болезни пока не найдено лекарства, а ее последствия хорошо заметны не только при попытке въехать на территорию ЕС или США. Примером оказывается и отношение к России. Основная часть информации об этой стране представляется на Западе в отрицательном свете, а западные журналисты воспринимают происходящее в этой стране весьма однобоко:

Теперь куда ни приедешь, в Японию или в Ригу, вокруг тебя все дышит подозрением.

- Ну, как там у вас, плохо?

- Почему плохо?

- А что, хорошо, что ли?

Особенно сбесились ихние журналисты. Причем поголовно. Чего они только не пишут! У вас, говорят, Путин - белый православный царь, который будет теперь править вечно.

- Да Бог с вами, почему вечно?

- Значит, вы - сторонник диктатуры?

- Какой такой диктатуры?

- Чекистской! Вы что, не слышали, что Путин собирается себя клонировать?

- Ребята, вы что! У нас тут терроризм. Нам надо вместе бороться против общего врага.

- А кто первым объявил Кавказу лингвистическую войну? [Ерофеев 2004d, 27].

Русский писатель обращает внимание на стереотипное восприятие России Западом. Его родина, независимо от настоящей и подвергающейся изменениям обстановки, воспринимается жителями Запада (при помощи СМИ) как диктатура, в которой нет никаких свобод. Иностранные журналисты, на основании поверхностного представления о России, создают образ, который отталкивает другие государства. Ерофеев замечает, что на Западе «они там становятся все более уверенными в том, что знают о нас больше и подробнее, чем мы сами, поскольку у нас нет возможности получать объективную информацию» [Ерофеев 2004b]. Западное представление о российской диктатуре сильно 
укоренилось и именно поэтому Ерофеев, как русский писатель, имеющий возможность свободно путешествовать и высказывать свое мнение, воспринимается на Западе с неким подозрением: «Смысл этого подозрения: если ты такой независимый или хочешь таким являться, то как тебя к нам выпускают?» [там же].

Автор Русской красавииь, не являющийся убежденным сторонником нынешнего президента $\mathrm{P} \Phi^{12}$, подчеркивает, что негативный образ России, создаваемый западными СМИ, может быть результатом не только стереотипного и поверхностного восприятия его родины. Свою роль здесь играет и определенный политический интерес. Россия оказывается фактором, способствующим сплочению США с западноевропейскими государствами, а также притягивающим к Западу другие, опасающиеся «российского авторитаризма», страны. Общий враг может хорошо укрепить дружбу между государствами:

Я не знаю тонкостей высшей европейской политики, мне трудно судить о намерениях НАТО, но, кажется, нас все со всех сторон по крайней мере немножко обманывают. Общественное мнение во всяком случае тех немецких людей, которые читают книжки, убеждено, что нам здесь в России пришел капут. Россия - это цензура, авторитаризм, война в Чечне, коррупция и нищета. Именно поэтому, от страха перед Россией, все бывшие советские союзники и республики бегут в НАТО, которое не позволит теперь разговаривать разным думским деятелям по-хамски с маленькой Литвой - НАТО может и кулаком стукнуть. Уже и братья болгары там [там же].

Создавая обманчивый образ России и не пытаясь поддерживать российских сторонников перемен, политики Западной Европы и США демонстрируют свою политическую близорукость. В будущем они могут быть крайне удивлены последствиями таких действий.

Образ Запада, создаваемый Ерофеевым, удивляет большим количеством негативных замечаний. Такой критический подход к Западу человека, являющегося убежденным сторонником западных перемен в России, кажется странным. Ерофеев считает страны Западной Европы и США хотя и неидеальным, но единственным приемлемым для

12 Об отношении Ерофеева к политической деятельности Путина см., например: [Ерофеев 2011; 2007]. См. также открытое письмо Ерофеева Путину по поводу акций молодежной организации «Идущие вместе»: [Ерофеев 2008c]. Письмо впервые публиковалось в газете Время $M H 5$ сентября 2002 года и было озаглавлено Особенности начиональной травли писателей. 
России образцом для подражания [См., например, Ерофеев 2003с; Ерофеев 2006a, 10-11].

Взгляды писателя относительно стран Запада связаны с западнической традицией в русской политико-общественной мысли. Ерофеев подчеркивает значение индивидуализма, личности и плюрализма ценностей, например, не соглашаясь с мнением большинства и негативными последствиями политкорректности. Какие-либо проявления нетерпимости воспринимаются им отрицательно. Кроме того, он убежден, что возможность свободно обмениваться идеями, путешествовать - это фактор, положительно влияющий на любое общество и именно поэтому ему хотелось бы отменить визовый режим со странами ЕС. Одобрение Ерофеевым системы социальной помощи, существующей в США, свидетельствует о том, что он является сторонником социальной справедливости.

Ерофеев не скрывает своего интереса к Западу, но, несмотря на многолетний опыт жизни в Западной Европе, он одновременно помнит о своей родине и ее проблемах. В результате он особо сильно чувствует различия между Россией и Западом:

Я офранцузил Россию и обрусил Париж. Всего того, что я ношу в себе, на самом деле нет. Я выдумал оба мира. В себе самом я их скрестил. Я, видимо, тот самый русский европеец, который и не европеец, и не русский.

У меня получилось то, что не получается. Можно ли меня считать удачным гибридом? Я потерял возможность абсолютных критериев. Поскольку два мира не совпадают, я ощущаю превратности морали [...].

Я хочу жить на два дома. Мне тесно в том и другом мире. Мне нужна хотя бы поочередность, лучше бы - совместность, в идеале - совместимость. Последнее я не нашел. Но я все равно не их, потому что мне там чего-то не хватает [Ерофеев 1999, 108].

\section{Литература}

Блок А., 1960, Скифы, [в:] А. Блок, Собрание сочинений в восьми томах, т. 3, Москва - Ленинград, с. 360-362.

Колаковский Л., 1974, Похвала непоследовательности, [в:] Л. Колаковский, Похвала непоследовательности, пер. с польского В. Кольцова, Firenze, c. $297-311$.

Ерофеев В., 1985, На грани разрыва ('Мелкий бес' Ф. Сологуба на фоне русской реалистической традичии), „Вопросы литературы”, № 2, с. 140-158. 
Ерофеев В., 1999, Энииклопедия русской души. Роман с энииклопедией, Москва.

Ерофеев В., 2001, Гурам на смех, (интервью Е. Кудрявцевой), „Огонек”, № 41, c. $32-35$.

Ерофеев В., 2002, Ностальгия по Варшаве, „Огонек”, № 22, с. 21.

Ерофеев В., 2003а, Восточный элемент, „Новые Известия”, 16 сентября 2003, [online], http://www.newizv.ru/society/2003-09-16/1334-viktor-erofe ev.html [01.07.14].

Ерофеев В., 2003b, Киношок писателя Ерофеева, (интервью Е. Варкан), „Огонек", № 36, с. 46-48.

Ерофеев В., 2003c, Парадоксы русского Севера, „Новые Известия”, 30 октября 2003, [online], http://www.newizv.ru/society/2003-10-30/2464-viktor-erofe ev.html [29.06.14].

Ерофеев В., 2003d, Последняя любовь Кафки, „Новые Известия”, 26 августа 2003, [online], http://www.newizv.ru/society/2003-08-26/786-viktor-erofeev .html [01.07.14].

Ерофеев В., 2004a, Будь я поляком..., [в:] А. де Лазари (ред.), Польская и русская душа (от Адама Мицкевича и Александра Пушкина до Чеслава Милоша и Александра Солженииьна), Варшава, с. 460-463.

Ерофеев В., 2004b, Нас опять подозревают, „Новые Известия”, 14 апреля 2004, [online], http://www.newizv.ru/society/2004-04-14/5929-viktor-erofe ev.html [29.06.14].

Ерофеев В.,2004c, Необькновенный фашизм, „Московские Новости”, № 22, c. 20 .

Ерофеев В., 2004d, Ну почему нас никто не любит?, „Московские Новости”, № 41 , с. 27.

Ерофеев В., 2004е, Охота к перемене мест, „Московские Новости”, № 39, с. 23.

Ерофеев В., 2006а, Детская болезнь любви $к$ хулиганам, „Огонек”, № 11, c. $10-11$.

Ерофеев В., 2006b, Европейский способ жизни, „Огонек”, № 20, с. 10-11.

Ерофеев В., 2006с, Маркиз де Сад, садизм и ХХ век, [в:] В. Ерофеев, Лабиринт Два. Остается одно: произвол, Москва, с. 222-273.

Ерофеев В., 2007, Путин - это расплата за грехи нашей демократии, [online], http://www.inosmi.ru/inrussia/20071221/238561.html [12.02.13]. Статья впервые публиковалась в дневнике „Телеграф”, (Латвия).

Ерофеев В., 2008а, Композитор судьбы, [в:] В. Ерофеев, Русский апокалипсис. Опьт художественной эсхатологии, Москва, с. 60-71.

Ерофеев В., 2008b, Любит ли нас наша родина?, [в:] В. Ерофеев, Русский апокалипсис. Опьт художественной эсхатологии, Москва, с. 143-146.

Ерофеев В., 2008c, Мочить писателей в сортире (Открытое письмо Президенту России В.В. Путину), [в:] В. Ерофеев, Русский апокалипсис. Опьт художественной эсхатологии, Москва, с. 298-301. 
Ерофеев В., 2008d, Разведчики дикой крови, [в:] В. Ерофеев, Свет дьявола. География смьсла жизни, Москва, с. 36-50.

Ерофеев В., 2008е, Свет дьявола. География смысла жизни, Москва.

Ерофеев B., 2008f, Солнчепек, [в:] В. Ерофеев, Русский апокалипсис. Onьт художественной эсхатологии, Москва, с. 225-229.

Ерофеев В., 2008g, Сто «оруэллов», [в:] В. Ерофеев, Русский апокалипсис. Oпьт художественной эсхатологии, Москва, с. 254-256.

Ерофеев В., 2008h, Три Польши, [в:] В. Ерофеев, Свет дьявола. География смысла жизни, Москва, с. 142-146.

Ерофеев В., 2010а, Вот вам виза..., „Радио Свобода” (интернет-сайт), 4 августа 2010, [online], http://www.svobodanews.ru/articleprintview/2118305. html [01.07.14].

Ерофеев В., 2010b, Катьнь больше, чем Катынь, „Независимая газета”, 19 апреля 2010, [online], http://www.ng.ru/ideas/2010-04-19/9 katyn.html [01.07. 14].

Ерофеев В., 2010с, Хороший Сталин, Москва.

Кантор В., 2001, Русский европееи как явление культурь (философско-исторический анализ), Москва.

Скоропанова И., 2002, Русская постмодернистская литература: новая философия, новый язык, Санкт-Петербург.

Щукин В., 2001, Русское западничество. Генезис-сущность - историческая роль, Łódź.

Arendt H., 1977, Eichmann in Jerusalem. A Report on the Banality of Evil, New York.

Bäcker R., 2000, Międzywojenny eurazjatyzm. Od intelektualnej kontrakulturacji do totalitaryzmu?, Łódź.

Buruma I., A. Margalit., 2005, Okcydentalizm. Zachód w oczach wrogów, пер. с английского A. Lipszyca, Kraków.

Erofeyev V., 2007, Moscow's Image Problem, „The International Herald Tribune”, 21 января 2007, [online], http://www.nytimes.com/2007/01/21/opinion/ 21iht-edviktor.4278822.html [30.06.14].

Erofeyev V., 2011, Putin? Oh, What a Surprise!, „The International Herald Tribune", 26 сентября 2011, [online], http://www.nytimes.com/2011/09/27/ opinion/27iht-ederofeyev27.html?_r=0 [30.06.14].

Judt T., 2008, Reappraisals. Reflections on the Forgotten Twentieth Century, New York.

Szahaj A., 2012, Wielość, względność, obojętność? O sekularyzacji i roli religii w debacie publicznej [в:] A. Szahaj, Liberalizm, wspólnotowość, równość. Eseje z filozofii polityki, Toruń, s. 97-114.

Walicki A., 1964, W kregu konserwatywnej utopii. Struktura i przemiany rosyjskiego stowianofilstwa, Warszawa. 


\section{VICTOR EROFEYEV'S VIEWS ON THE WEST}

\section{S U M M A R Y}

This paper presents the views of Victor Erofeyev, a Russian writer and columnist, on the West. The author of this paper makes an attempt to show Erofeyev's views on Western Europe and the USA, focusing particularly on selected aspects of the Western reality (religion, political correctness, politics, capitalism, mentality) as well as the West's approach to Russia.

Erofeyev's views are determined by his opinion on society and politics. The author of this paper shows the relationship between Erofeyev's approach to the West and the Westernizers' movement, a Russian intellectual movement of the 19th century. The author also demonstrates how Erofeyev's views are part of the Westernizers' tradition in Russia's intellectual life.

Łukasz Giemziak e-mail: lukgem@o2.pl 